Original Research Paper

\title{
Peningkatan Kompetensi Guru IPA Kota Mataram dalam Memfasilitasi Penguasaan Keterampilan Abad Ke 21 Siswa SMP
}

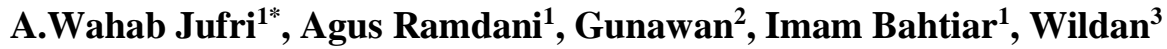 \\ ${ }^{1}$ Program Studi Pendidikan Biologi Fakultas Keguruan dan Ilmu Pendidikan, Universitas Mataram \\ ${ }^{2}$ Program Studi Pendidikan Fisika Fakultas Keguruan dan Ilmu Pendidikan, Universitas Mataram \\ ${ }^{3}$ Program Studi Pendidikan Kimia Fakultas Keguruan dan Ilmu Pendidikan, Universitas Mataram
}

*Corresponding Author:

A.Wahab Jufri, Program Studi Pendidikan Biologi Fakultas Keguruan dan Ilmu Pendidikan, Universitas Mataram, Indonesia;

Email: awahabjufri@unram.ac.id

\begin{abstract}
Abstrak: Kebanyakan guru IPA di jenjang SMP belum mampu mengintegrasikan unsur-unsur keterampilan abad ke-21 dalam pembelajaran IPA di kelas. Pengalaman dalam berinteraksi dengan guru IPA dan mahasiswa calon guru IPA di pulau Lombok, mengindikasikan bahwa mereka belum memiliki kemampuan yang optimal dalam merancang perangkat pembelajaran maupun instrumen penilaian yang berorientasi pada perkembangan keterampilan abad ke-21 yang seharusnya dikuasai oleh peserta didik tingkat SMP. Sehubungan dengan hal tersebut, perlu dilakukan upaya untuk memberdayakan kemampuan guru dalam mengasses hasil belajar IPA siswa terutama yang terkait dengan penguasaan unsur-unsur keterampilan abad ke-21 terutama keterampilan berpikir dan literasi sains. Pengabdian pada masyarakat ini dilaksanakan dengan tujuan untuk: 1) memfasilitasi peningkatan kompetensi guru IPA dalam mengasses hasil belajar peserta didik, dan 2) melatih guru mengembangkan instrumen yang berorientasi pada keterampilan abad ke-21 secara terintegrasi dengan materi pelajaran IPA SMP. Materi pengabdian pada masyarakat ini diharapkan memberi manfaat dalam membantu meningkatkan kompetensi guru dalam merancang instrumen pembelajaran IPA yang memuat unsur-unsur keterampilan abad ke-21 pada dirinya sendiri dan pada peserta didiknya. Permasalahan yang menjadi fokus pengabdian masyarakat ini adalah terbatasnya kemampuan guru IPA dalam merancang instrumen untuk mengasses penguasaan unsur-usur keterampilan abad ke-21 seperti literasi sains, berpikir kritis, dan kreativitas siswa. Strategi yang diterapkan dalam kegiatan pengabdian ini antara lain ialah: (1) melaksanakan penyuluhan kepada guru-guru IPA SMP di kota Mataram, (2) melaksanakan pelatihan terstruktur untuk merancang instrumen penilaian hasil belajar IPA yang berorientasi pada keterampilan abad ke-21. Luaran yang telah dihasilkan melalui pengabdian pada masyarakat ini adalah: 1) terlaksananya sosialisasi dan pengembangan pemahaman tentang keterampilan abad ke 21 dan instrumen penialainnya bagi para guru IPA SMP di kota Mataram, 2) terlaksananya pelatihan merancang instrumen hasil belajar IPA yang efektif untuk mengasses penguasaan keterampilan abad ke-21 siswa SMP, 3) tersusunnya artikel hasil pengabdian pada masyarakat yang dipublikasikan dalam jurnal ilmiah.
\end{abstract}

Kata Kunci: instrumen, hasil belajar, keterampilan abad ke-21

\section{Pendahuluan}

Reformasi pendidikan sains harus diarahkan untuk memaksimalkan perkembangan keterampilan abad ke-21 (NRC, 1996) yang meliputi keterampilan berpikir kritis dalam keterampilan menyelesaikan masalah, kreativitas, keterampilan bekerjasama, dan keterampilan berkomunikasi peserta didik (NEA, 2009). Keterampilan berpikir kritis dan kreativitas merupakan komponen modal intelektual yang diyakini dapat meningkatkan kemampuan peserta didik dalam menyelesaikan masalah dan mengambil keputusan melalui proses kerjasama dan komunikasi yang efektif. Keseluruhan aspek tersebut sangat dibutuhkan oleh generasi muda masa depan agar mampu berkompetisi dalam persaingan era global. Kenyataan yang ada dalam dunia pendidikan kita 
mulai dari jenjang sekolah dasar sampai dengan sekolah menengah adalah bahwa keterampilan abad ke-21 siswa masih kurang mendapat perhatian dari para pendidik. Kurangnya perhatian pendidik berkaitan erat dengan rendahnya kemampuan pendidik dalam merencanakan, melaksanakan, dan mengevaluasi khususnya menyusun instrumen hasil pembelajaran yang berpotensi untuk mengembangkan keterampilan abad ke-21 siswa sebagai bagian hasil belajar (Jufri \& Soelistya, 2010, Jufri, 2013).

Kemampuan berpikir tingkat tinggi adalah modal intelektual yang sangat perlu dikembangkan melalui proses pembelajaran sains di sekolah. Berkaitan dengan pembelajaran sains (IPA) di tingkat sekolah menengah (Depdiknas, 2003) mengisyaratkan ada 6 pertimbangan penting yang harus diperhatikan oleh guru, yakni: 1) empat pilar pendidikan, 2) belajar melalui inkuiri, 3) konstruktivisme, 4) sains, teknologi, dan masyarakat, 5) penyelesaian masalah, dan 6) pembelajaran yang bermuatan nilai. Berdasarkan pertimbangan tersebut, maka guru diharapkan dapat berperan sebagai fasilitator, pembimbing dan teman bagi siswa dalam mengembangkan keterampilan berpikir tingkat tinggi melalui kegiatan belajar (OECD, 2012).

Sehubungan dengan pertimbangan di atas, maka guru-guru bidang sains seharusnya mampu memberikan perhatian penuh pada upaya untuk meningkatkan dan mengembangkan kemelekan sains (science literacy), dan kemelekan inkuiri (inquiry literacy) sebagai materi dan proses sains. Pemahaman tentang inkuiri ilmiah merupakan faktor penting yang harus dipahami dan dipraktikkan oleh guru dalam membelajarkan IPA. Dalam hal ini, guru dituntut untuk dapat memfasilitasi siswa agar berusaha membangun pengetahuan dan keterampilannya secara mandiri. Oleh karena itu, guru IPA di semua jenjang pendidikan seharusnya mampu merancang dan menerapkan pembelajaran sains dengan lebih mementingkan perkembangan keterampilan berpikir, kemampuan bekerjasama, dan literasi sains siswa secara positif. Pengembangan kualitas keterampilan berpikir dapat dilakukan melalui perancangan dan penerapan model-model pembelajaran yang melibatkan siswa secara aktif dalam rangkaian proses belajar. Selain itu, guru juga harus mampu mengembangkan strategi dan instrument yang relevan untuk mengasses sekaligus memfasilitasi berkembangnya keterampilan- keterampilan yang penting bagi siswa dalam menghadapi tantangan abad ke 21 .

Permasalahan umum berkaitan dengan kualitas pendidikan IPA adalah kemampuan siswa dalam penguasaan keterampilan abad ke-21 seperti keterampilan berpikir kritis, dan literasis sains. Hal ini tentu tidak terlepas dari kurangnya kemampuan guru dalam merancang pembelajaran serta instrumen penilaian yang mendukung perkembangan keterampilan siswa.

Salah satu upaya yang penting untuk dilakukan adalah dengan memberi pelatihan dan pendampingan pada guru-guru IPA dalam merancang perangkat pembelajaran khususnya instrumen yang relevan untuk mengasses dan menilai perkembangan literasi ilmiah, keterampilan berpikir kritis dan berpikir kreatif peserta didik. Berkaitan dengan permasalahan tersebut maka solusi yang dilaksanakan melalui kegiatan pengabdian pada masayarakat ini adalah dengan : (1) Melaksanakan sosialisasi untuk meningkatkan pemahaman guru terhadap unsur-unsur keterampilan abad ke 21 serta model instrumen penilaiannya, pada guru-guru IPA anggota MGMP IPA di kota Mataram, (2) Melatih guru-guru IPA anggota MGMP kota Mataram untuk mengembangkan instrumen untuk mengasses penguasaan siswa terhadap unsur-unsur keterampilan abad ke 21.

Adapun tujuan dari kegiatan pengabdian ini adalah untuk: (1) meningkatkan pemahaman guru IPA menenai komponen-komponen keterampilan abad ke-21, dan (2) membimbing guru-guru IPA SMP untuk berlatih merancang instrument untuk mengasses penguasaan keterampilan abad ke-21 siswa SMP. Ketercapaian tujuan-tujuan tersebut diharapkan dapat memberikan manfaat berupa terjadinya peningkatan kompetensi guru dalam mengembangkan instumen pembelajaran IPA yang berorientasi pada pengusasaan keterampilan abad ke 21 pada siswa SMP.

\section{Metode}

Kegiatan pengabdian pada masyarakat ini dilaksanakan dengan pendekatan konstruktivisme berorientasi pola pembelajaran orang dewasa (andragogy) yang diitegrasikan dalam metode yaitu ceramah, tanya jawab, diskusi kelompok, dan metode drill (latihan). Metode ceramah, tanya 
jawab, dan diskusi kelompok diterapkan dalam pelaksanaan kegiatan tahap pertama yakni pada tanggal 6 Oktober 2019 di SMPN 10 Mataram, dengan tujuan untuk memberikan pemahaman kepada guru tentag pentingnya pembekalan materi keterampilan abad ke 21 kepada siswa SMP. Adapun metode diskusi kelompok dan pelatihan (drill) diterapkan dalam kegiatan pengabdian pada tanggal 20 Oktober 2018 yang dilaksanakan di ruang kuliah 2.1 gedung Program Studi Farmasi, atas izin Dr. Yayuk Andayani, M.Si selaku ketua Program Studi Farmasi di Universitas Mataram.

\section{Hasil dan Pembahasan}

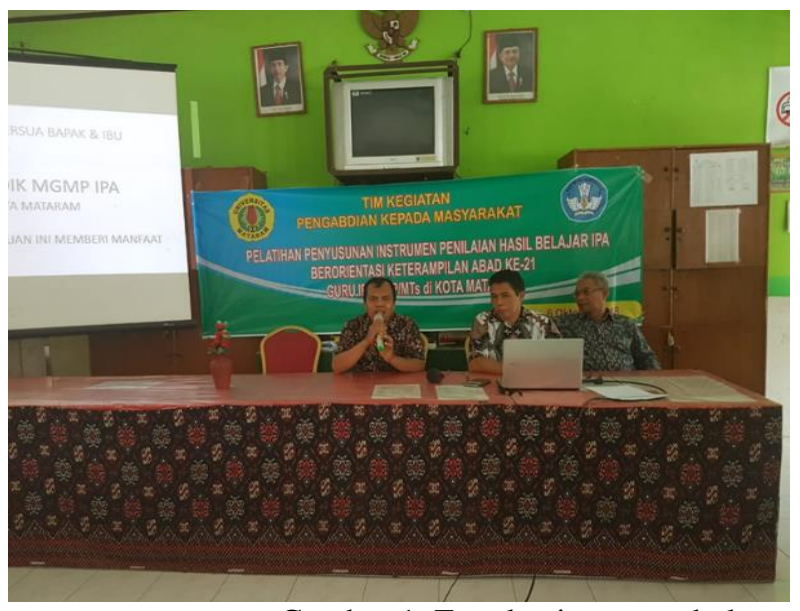

Kegiatan pada tahap pertama tanggal 6 Oktober 2018 diisi dengan penyajian materi yang meliputi: (1) Keterampilan Abad ke 21, Tantangan Pendidik IPA dan Kebutuhan Generasi Masa Depan (disajikan oleh Dr. A. Wahab Jufri), (2) Analisis Kompetensi Dasar dan Instrumen Pendidikan IPA SMP, disajikan oleh Dr. Agus Ramdani, (3) Strategi Pengembangan Instrumen Keterampilan Abad ke 21, disajikan oleh Dr. Imam Bachtiar dan Dr. Wildan), dan (4) Contoh-contoh Instrumen Berorientasi Keterampilan Abad ke 21, disampaikan oleh Dr. Gunawan. Berikut ini disajikan beberapa dokumen/gambar pada saat pelaksanaan kegiatan tahap pertama.

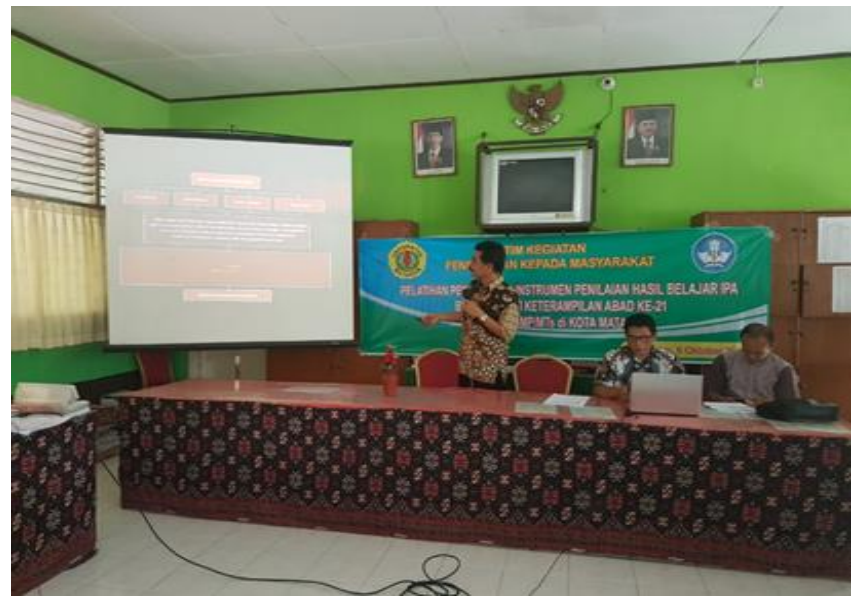

Gambar 1. Foto kegiatan pembukaan dan penyajian materi oleh tim di SMPN 10.

Kegiatan tahap pertama ini diikuti oleh 32 orang guru dari beberapa SMPN di kota Mataram. Guru-guru peserta sangat antusias mengikuti kegiatan, terbukti dari munculnya pertanyaan- pertanyaan yang diajukan baik dalam diskusi kelas kepada tim pengabdi maupun antar sesama peserta dalam aktivitas diskusi kelompok.
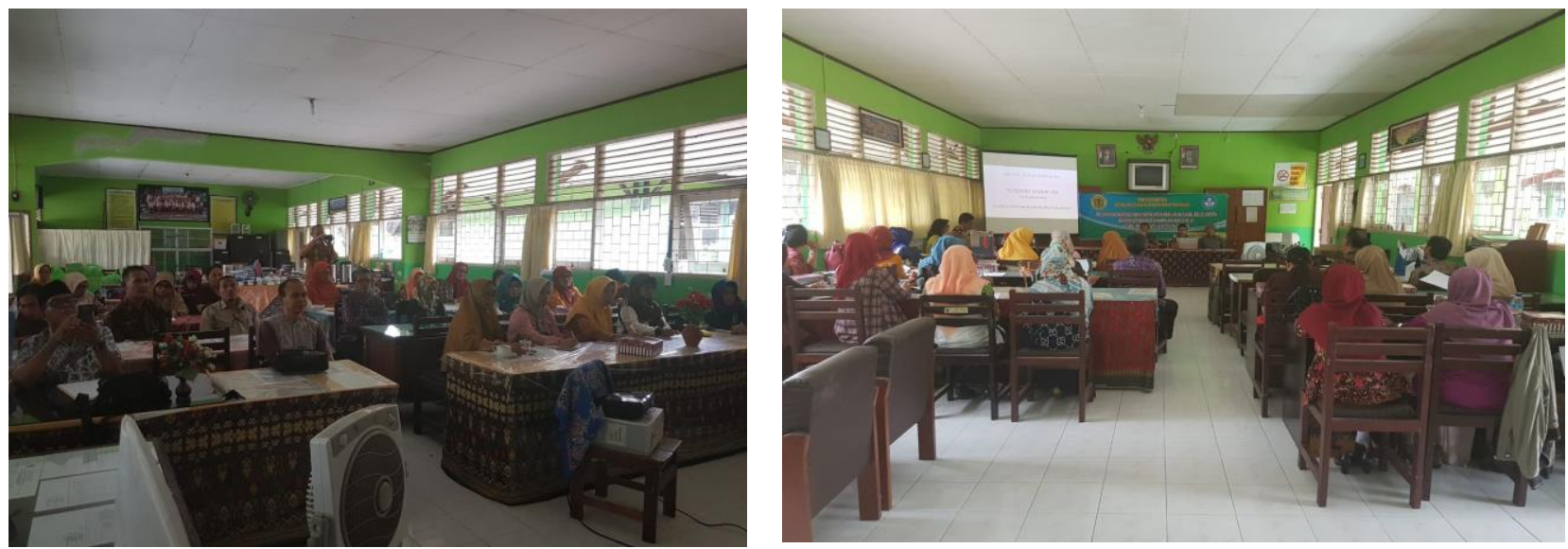

Gambar 2. Suasana kelas pada saat penyajian materi keterampilan abad ke 21. 
Hasil yang diperoleh pada tahap ini memperkuat asusmsi yang melatar belakangi pentingnya pengabdian kepada masyarakat ini dilakukan yakni tentang lemahnya penguasaan/pemahaman guru mengenai materi keterampilan abad ke-21 serta rendahnya kompetensi dalam mengembangkan instrumen untuk mengasses penguasaan keterampilan oleh siswa. Fakta tentang hal ini terungkap dari proses dan hasil diskusi yang terjadi dalam kelas ketika berlangsungnya sosialisasi. Temuan seperti ini memperkuat hasil penelitian yang telah dilakukan oleh sebagian anggota tim. Misalnya Jufri, dkk (2017) menemukan bahwa tingkat literasi sains dan pedagogical content knowledge guru dan calon guru IPA masih tergolong rendah, seperti halnya dengan temuan (Ramdani, dkk., 2016) yang menemukan bahwa keterampilan berpikir dan penguasaan inkuiri ilmiah sebagai pola ideal pelaksanaan pembelajaran IPA.

Mengacu pada hasil kegiatan tahap pertama, maka tim pengabdian kepada masyarakat ini merancang pertemuan tahap kedua dengan tujuan untuk melatih para guru partisipan dalam merancang instrumen untuk mengasses penguasaan siswa terhadap keterampilan abad ke 21. Setelah membuat kesepakatan waktu dan tempat kegiatan berikutnya, maka diputuskan bahwa tahapan kedua dari pengabdian ini dilaksanakan di Program Studi S1 Farmasi Universitas Mataram, pada hari Sabtu, tanggal 20 Oktober 2018.

Mekanisme interaksi dalam kegiatan tahap ini dimulai dengan kegiatan curah pendapat dan diskusi bersama guru-guru partisipan mengenai strategi dan pola pengembangan instrument. Fokus sajian dan diskusi meliputi model soal yang mengacu pada taksonomi SOLO dan model-model tes literasi ilmiah (scientific literacy). Pola interaksi yang diterapkan dalam kegiatan pada tahap ini adalah metode diskusi kelompok dan metode latihan (drill). Kegiatan diskusi kelompok berlangsung dengan dinamis dan penuh semangat dari peserta. Gambar 1 berikut menunjukkan aktivitas diskusi dan kerja kelompok menganalisis kompetensi dasar dan merancang instrumen untuk mengasses penguasaan keterampilan abad ke 21 .
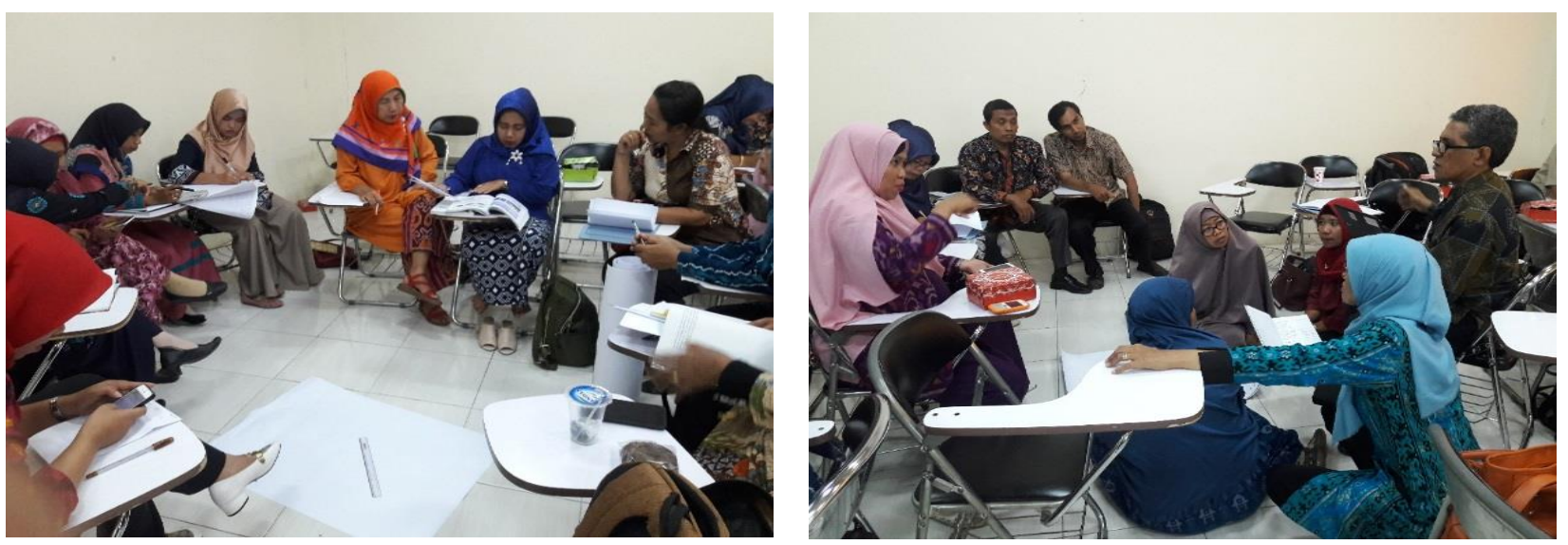

Gambar 3. Suasana kelas pada saat peserta berdiskusi/bekerja kelompok.
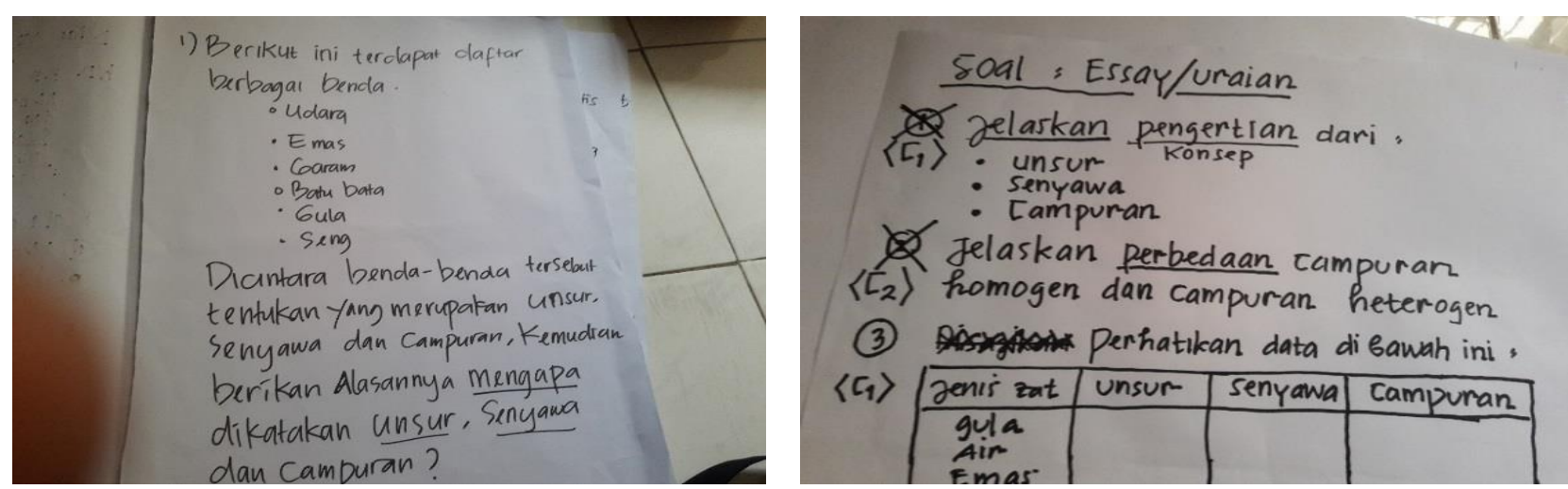

Gambar 4. Rumsan pertanyaan dalam tugas kelompok sebelum intervensi. 
Berdasarkan hasil pengamatan pada saat kerja kelompok peserta, ditemukan sebagaian besar peserta masih kurang mampu merumuskan kalimat pertanyaan yang menantang kemampuan berpikir siswa. Sebagai contoh dalam Gambar 4 ditunjukkan rumusan pertanyaan yang dihasilkan oleh dua kelompok peserta. Rumusan pertanyaan dalam kedua lembaran hasil kerja peserta dalam gambar tersebut merupakan contoh pertanyaan yang tagihannya hanya mengacu pada literasi sains level rendah dan belum cukup relevan untuk mengasses keterampilan berpikir kritis siswa. Pertanyaan pertama yang meminta siswa memberi alasan pengklasikasian nama-nama benda tertentu menjadi unsur, senyawa, dan campuran hanya berdasarkan asumsi yang sulit dibuktikan melalui pengalaman langsung siswa dalam kelas. Pertanyaan kedua juga hanya menagih kemampuan siswa untuk menjelaskan pemahamannya mengenai suatu konsep dengan menggunakan kalimat yang tidak menantang dan bersifat ambigu. Kedua pertanyaan tersebut hanya menagih siswa untuk memberi penjelasan yang singkat yang bias jadi hanya berupa opini siswa.

Sehubungan dengan hasil pengamatan langsung tentang adanya kesulitan guru partisipan untuk menghasilkan soal atau pertanyaan yang lebih menantang, maka anggota tim selanjutnya mengintervensi diskusi kelompok para guru dengan mendatangi tiap-tiap kelompok secara bergilir. Tim pengabdian mencoba berdialog dan memberikan masukan mengenai strategi untuk meningkatkan kualitas tagihan dalam soal. Guru-guru partisipan mencoba memahami dan merumuskan pertanyaan dengan merekonstruksi yang sudah ada atau membuat pertanyaan yang baru. Beberapa rumusan pertanyaan yang dihasilkan setelah pendamingan dalam kelompok secara intensif, ditunjukkan dalam Gambar 5 di bawah ini.

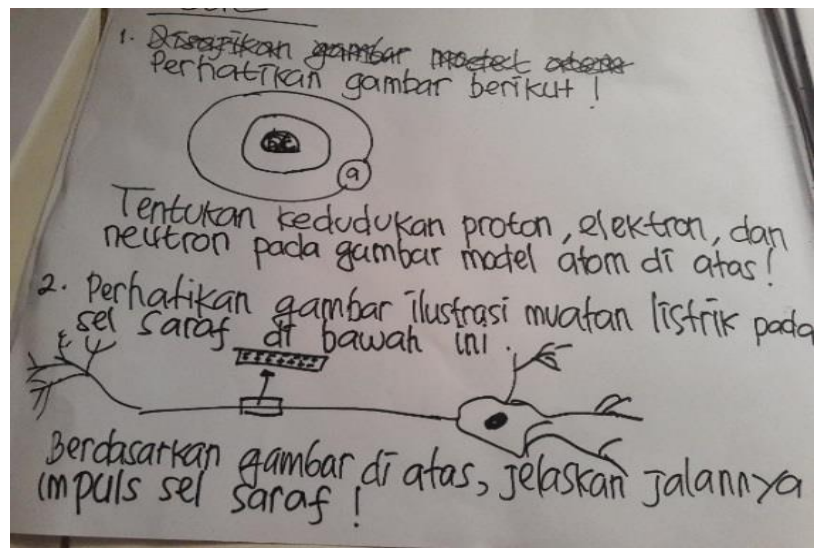

Gambar 5. Rumusan pertanyaan buatan guru setelah intervensi pendampingan.

\section{Kesimpulan}

Beberapa kesimpulan yang dapat diambil dari proses dan hasil pengabdian kepada masyarakat ini antara lain ialah: (1) Guru-guru IPA di kota Mataram masih belum mampu mengintegrasikan unsur-unsur keterampilan abad ke-21 dalam proses pembelajaran IPA. Setelah mengikuti kegiatan pengabdian ini terlihat adanya perkembangan kemampuan dan motivasi guru untuk mendalami pentingnya keterampilan abad ke 21; (2) Kompetensi guru-guru IPA di kota Mataram dalam merancang instrumen untuk mengasses keterampilan abad ke 21, dapat dikembangkan melalui proses diskusi dan pelatihan/pendampingan yang berkelanjutan.

\section{Saran-Saran}

Berdasarkan proses dan hasil yang diperoleh dalam kegiatan pengabdian kepada masyarakat ini dapat dikemukakan saran-saran: (1) Perlu adanya kerjasama kelembagaan berkelanjutan antara FKIP Unram dengan Dinas Pendidikan di kabupaten/kota maupun provinsi untuk bersamasama mengawal penjaminan kualitas kompetensi guru-guru IPA khusunya; (2) Dosen di LPTK yang akan melaksanakan kegiatan pengabdian kepada 
masyakat dengan sasaran guru di sekolah, diharapkan dapat merancang kegiatan yang memadukan proses penyuluhan yang berlanjut dengan pelatihan. Hal ini penting mengingat perkembangan kemampuan/kompetensi guru memerukan waktu dan proses yang berkesinambungan; (3) Bagi Dinas Pendidikan di kabupaten/kota dan provinsi agar memprogramkan peningkatan kualitas guru secara berkelanjutan melalui kerjasama intensif dengan LPTK-LPTK yang ada terutama FKIP Universitas Mataram, yang sampai dengan saat ini sudah memiliki tenagatenaga akademik dengan tandar kualifikasi dan kompetensi setara dengan dosen dari perguruanperguruan tinggi besar lainnya.

\section{Ucapan Terimakasih}

Seiring terlaksananya kegiatan pengabdian kepada masyarakat ini, disampaikan ucapan terimakasih kepada Rektor dan Ketua LPPM Universitas Mataram yang telah memberikan dana DIPA BLU dengan Surat Perjanjian Nomor 1304/UN18/LPPM/2018.

\section{Daftar Pustaka}

Depdiknas., 2003a. Kurikulum 2004 SMA, Pedoman Khusus Pengembangan Silabus dan Penilaian Mata Pelajaran Sains. Jakarta: Direktorat Jenderal Pendidikan Menengah Umum Departemen Pendidikan Nasional.

Jufri, AW., D. Setiadi, Sripatmi. 2016. Scientific Reasoning Ability of Prospective Student Teacher in the Excellence Program of Mathematics and Science Teacher Education in University of Mataram. Jurnal Pendidikan IPA UNNES, 5 (1), 69 - 74.

Jufri, AW . 2017. Belajar dan Pembelajaran Sains Modal Dasar Menjadi Guru Profesional. Penerbit Pustaka Reka Cipta. Bandung.

Jufri, AW \& D.J. Soelistya. 2010. Efektivitas Pembelajaran Sains Berbasis Inkuiri dengan Strategi Kooperatif dalam Meningkatkan Keterampilan Berpikir Siswa SMP. Jurnal Pendidikan dan
Pembelajaran Universitas Negeri Malang. No. 17 Volume 2.

OECD, 2012. PISA 2012 Results in Focus. What 15-year-olds Know and What They Can Do with What They Know. (Online):http//www.oecd.org/pisa/.../pisa -2012-results.htm. Diunduh tanggal 6 Februari 2015.

NEA, 2009. Preparing 21st Century Students for a Global Society, Educator's Guide to the "Four Cs" Great Public Schools for Every Student.

Ramdani, A., Jufri, A.W., Azizah, A. 2013. Model Pengembangan Pendidikan Karakter Melalui Pembelajaran Sains Biologi Berbasis Inkuiri Di Sekolah Menengah Pertama. Universitas Mataram: Kelompok Peneliti Bidang Ilmu "Edubio". 